\title{
Effect of cycloheximide on nuclear maturation of pig and mouse oocytes
}

\author{
J. Fulka, Jr, J. Motlík*, J. Fulka* and F. Jílek \\ Institute of Animal Production, 25161 Prague 10-Uhrínèves, and ${ }^{*}$ Czechoslovak Academy of \\ Sciences, Institute of Animal Physiology and Genetics, Department of Genetics, 27721 Liběchov, \\ Czechoslovakia
}

\begin{abstract}
Summary. Culture of mouse oocytes in medium with 1 or $100 \mu \mathrm{g}$ cycloheximide $/ \mathrm{ml} \mathrm{did}$ not prevent germinal vesicle breakdown (GVBD). In contrast, GVBD in pig oocytes was absolutely blocked at concentrations of $1,5,10,50$ and $100 \mu \mathrm{g}$ cycloheximide $/ \mathrm{ml}$, respectively. The inhibition of GVBD was not influenced by the presence or absence of cumulus cells and it was fully reversible. When cycloheximide treatment $(5 \mu \mathrm{g} / \mathrm{ml})$ was given after preincubation for 6,12 and $16 \mathrm{~h}$, GVBD occurred in 15,46 and $75 \%$ of oocytes, respectively. It is concluded that proteins important for GVBD of pig oocytes were present in sufficient amounts at about $12 \mathrm{~h}$ of culture.

The fusion of pig oocytes in metaphase $I$ to oocytes with an intact germinal vesicle revealed that cycloheximide did not inhibit GVBD induced by maturing ooplasm. Therefore, induction of prematurely condensed chromosomes by the maturing ooplasm did not require protein synthesis. However, continuous protein synthesis was necessary to maintain metaphase I and prematurely condensed chromosomes in a typical configuration.
\end{abstract}

\section{Introduction}

Protein synthesis plays an important role in the maturation of mammalian oocytes. Germinal vesicle breakdown (GVBD) is accompanied by qualitative and quantitative changes in the polypeptide pattern (McGaughey \& Van Blerkom, 1977; Warnes, Moor \& Johnson, 1977; Van Blerkom \& McGaughey, 1978). Mouse oocytes cultured in a medium with puromycin or cycloheximide cannot proceed beyond the circularly arranged bivalent stage (for review, see Mangia $\&$ Canipari, 1977; Schultz \& Wassarman, 1977). It means that GVBD in this species occurs independently of protein synthesis. Rat oocytes behave similarly, but when they are cultured in the presence of dbcAMP and puromycin and then in the medium with puromycin alone, GVBD is prevented (Ekholm \& Magnusson, 1979). These results indicate the existence of short-lived proteins necessary for the initiation of meiosis. If protein synthesis related to the resumption of meiosis is required for the first $9 \mathrm{~h}$ in sheep oocytes (R. M. Moor \& C. Polge, unpublished results, cited by Osborn \& Moor, 1983), then there may be differences between mammalian species in sensitivity of GVBD to inhibitors of protein synthesis.

In the present experiments, we have compared the effect of cycloheximide on maturation of mouse oocytes, which need only $2 \mathrm{~h}$ for GVBD (Donahue, 1968), and pig oocytes, in which GVBD takes 16-20 h (Motlík \& Fulka, 1976). The influence of cycloheximide on the appearance of prematurely condensed chromosomes after fusion was also tested.

\section{Materials and Methods}

Pig oocytes were obtained from ovaries of slaughtered animals by aspiration of antral follicles of about $5 \mathrm{~mm}$ in diameter. Only oocytes surrounded by compact cumuli were chosen for further 
experiments. Mouse oocytes were isolated from late antral follicles of sexually mature females (strain A) and only those containing germinal vesicles were used.

Pig and mouse oocytes were cultured in $0.1 \mathrm{ml}$ culture medium as droplets under paraffin oil at $38^{\circ} \mathrm{C}$ under $5 \% \mathrm{CO}_{2}$ in air according to the experimental scheme (see Tables 1 and 2). The culture medium contained $72 \mathrm{ml}$ isotonic TC 199 medium (Usol, Prague, Czechoslovakia), $18 \mathrm{ml} 1.45 \%$ $\mathrm{NaHCO}_{3}+0.002 \%$ phenol red, $10 \mathrm{ml} \mathrm{5.5 \%} \mathrm{(v/v)} \mathrm{glucose} \mathrm{solution,} 4 \mathrm{mg}$ sodium pyruvate, $10 \mathrm{mg}$ freeze-dried calf serum growth proteins $(\mathrm{Usol}) / \mathrm{ml}$, and 50 i.u. penicillin and $5 \mathrm{mg}$ streptomycin $/ \mathrm{ml}$. This medium was supplemented by cycloheximide (Serva, Heidelberg, FRG) at concentrations 1, 5, 10,50 or $100 \mu \mathrm{g} / \mathrm{ml}$.

For fusion of pig oocytes (see Table 3) cumuli oophori were removed mechanically and zonae pellucidae were dissolved by pronase treatment $(0 \cdot 5 \%)$. Pairs of these oocytes were agglutinated in the culture medium supplemented with phytohaemagglutinin $(100 \mu \mathrm{g} / \mathrm{ml}$; Burroughs Wellcome, U.K.). The contact between oocytes was achieved by means of a fine glass micropipette. The agglutinated cells were washed in protein-free medium and transferred to polyethylene glycol (Lachema, Brno, Czechoslovakia) of molecular weight 6000 in a $50 \%(w / v)$ concentration for 45-60 sec. After repeated washing in the culture medium, the fused cells were cultured in medium containing cycloheximide $(25 \mu \mathrm{g} / \mathrm{ml})$ as described above.

At the end of all culture intervals oocytes and fused cells were mounted on slides, fixed in acetic alcohol $(1: 3, \mathrm{v} / \mathrm{v})$ for at least $24 \mathrm{~h}$, stained with $1 \%$ orcein and examined under the phase-contrast microscope.

For the developmental stages of germinal vesicle in the process of maturation the criteria published by Motlik \& Fulka (1976) were used. In their criteria GV I represents an intact germinal vesicle with distinct nuclear membrane, finely granulated nucleoplasm and chromatin which is stained in the form of a ring only around a visible nucleolus. GV II is typical, with the appearance of orcein-positive zones localized on the nuclear membrane, and a discernible nucleolus. In GV III the nucleoplasm loses its granulation and, after staining, only the nucleolar area can be distinguished. The chromatin is distributed in well-stained clumps or filamentous bivalents always appear. GV IV is characterized by the chromatin occurring as more condensed individual bivalents, the nuclear membrane becoming less distinct and the nucleolus is completely absent.

\section{Results}

The present results confirmed that cycloheximide did not influence resumption of meiosis in mouse oocytes (Table 1). Concentrations of 1 or $100 \mu \mathrm{g} / \mathrm{ml}$ did not prevent GVBD. In contrast, pig oocytes were influenced by cycloheximide at a very low concentration. While about $90 \%$ of oocytes underwent GVBD in the control medium after $24 \mathrm{~h}$ of culture, all concentrations of cycloheximide (from 1 to $100 \mu \mathrm{g} / \mathrm{ml}$ ) completely blocked GVBD. The inhibition of GVBD was not influenced by the presence or absence of cumulus cells. To check that these results were not caused by a toxic effect of cycloheximide, the reversibility of the meiotic block was tested. After $24 \mathrm{~h}$ of culture in medium with $5 \mu \mathrm{g}$ cycloheximide/ml, oocytes were thoroughly washed in the culture medium and cultured for the following $24 \mathrm{~h}$ without cycloheximide. GVBD occurred in 112 of 117 cultured oocytes $(95 \%)$.

To test the time of in-vitro maturation when protein synthesis important for GVBD of pig oocytes occurred, pig oocytes were preincubated for 6,12 and $16 \mathrm{~h}$ in culture medium and then cultured in the presence of $5 \mu \mathrm{g}$ cycloheximide $/ \mathrm{ml}$ for an additional 18,12 and $8 \mathrm{~h}$, respectively. All oocytes fixed after $6 \mathrm{~h}$ of preincubation were in GV I. After $18 \mathrm{~h}$ of culture in medium with $5 \mu \mathrm{g}$ cycloheximide/ml only $15 \cdot 3 \%$ of oocytes underwent GVBD (Table 2). After $12 \mathrm{~h}$ of preincubation oocytes at GV II predominated, and only $6 \%$ did not possess a germinal vesicle. Subsequent culture for $12 \mathrm{~h}$ in cycloheximide led to GVBD in $46 \%$ of oocytes. After $16 \mathrm{~h}$ of preincubation, oocytes were mainly in GV III and GV IV and about 20\% exhibited GVBD. Further culture for $8 \mathrm{~h}$ 
Table 1. Effect of cycloheximide on nuclear maturation of mouse and pig oocytes

\begin{tabular}{|c|c|c|c|c|c|c|c|}
\hline \multirow[b]{2}{*}{ Species } & \multirow[b]{2}{*}{$\begin{array}{l}\text { Time of } \\
\text { culture }\end{array}$} & \multirow[b]{2}{*}{$\begin{array}{l}\text { Type of } \\
\text { culture* }\end{array}$} & \multirow{2}{*}{$\begin{array}{l}\text { Conc. } \\
\text { cycloheximide } \\
(\mu \mathrm{g} / \mathrm{ml})\end{array}$} & \multirow[b]{2}{*}{$\begin{array}{l}\text { No. of } \\
\text { oocytes }\end{array}$} & \multicolumn{3}{|c|}{ No. of oocytes: } \\
\hline & & & & & $\begin{array}{l}\text { With } \\
\text { GV }\end{array}$ & $\begin{array}{l}\text { With } \\
\text { GVBD }\end{array}$ & Degenerated $\dagger$ \\
\hline Mouse & $6 \mathrm{~h}$ & $\begin{array}{l}\mathrm{C}+ \\
\mathrm{C}+ \\
\mathrm{C}+\end{array}$ & $\begin{array}{r}0 \\
1 \\
100\end{array}$ & $\begin{array}{l}40 \\
40 \\
40\end{array}$ & $\begin{array}{l}3 \\
5 \\
8\end{array}$ & $\begin{array}{l}37 \\
35 \\
52\end{array}$ & \\
\hline Pig & $24 \mathrm{~h}$ & $\begin{array}{l}\mathrm{C}+ \\
\mathrm{C}+ \\
\mathrm{C}- \\
\mathrm{C}+ \\
\mathrm{C}+ \\
\mathrm{C}+ \\
\mathrm{C}+\end{array}$ & $\begin{array}{r}0 \\
1 \\
1 \\
5 \\
10 \\
50 \\
100\end{array}$ & $\begin{array}{l}44 \\
71 \\
64 \\
61 \\
66 \\
59 \\
56\end{array}$ & $\begin{array}{r}5 \\
66 \\
61 \\
60 \\
63 \\
58 \\
55\end{array}$ & $\begin{array}{r}39 \\
1\end{array}$ & $\begin{array}{l}4 \\
3 \\
1 \\
3 \\
1 \\
1\end{array}$ \\
\hline
\end{tabular}

* Oocytes were cultured with a compact cumulus $(\mathrm{C}+)$ or the cumulus was removed mechanically before culture $(\mathrm{C}-)^{2}$

$\dagger$ Oocytes in which the stage of maturation could not be recognized by phase-contrast microscopy.

Table 2. Effect of oocyte preincubation on cycloheximide block of nuclear maturation in pig

\begin{tabular}{|c|c|c|c|c|c|c|}
\hline \multicolumn{2}{|c|}{ Time of culture (h) in } & \multirow[b]{2}{*}{$\begin{array}{l}\text { No. of } \\
\text { oocytes }\end{array}$} & \multicolumn{3}{|c|}{ No. of oocytes: } & \multirow[b]{2}{*}{$\begin{array}{l}\% \text { of } \\
\text { GVBD }\end{array}$} \\
\hline $\begin{array}{l}\text { Control } \\
\text { medium }\end{array}$ & $\begin{array}{l}\text { Medium with } 5 \mu \mathrm{g} \\
\text { cycloheximide } / \mathrm{ml}\end{array}$ & & $\begin{array}{l}\text { With } \\
\text { GV }\end{array}$ & $\begin{array}{l}\text { With } \\
\text { GVBD }\end{array}$ & Degenerated* & \\
\hline $\begin{array}{l}6 \\
6\end{array}$ & $\begin{array}{r}0 \\
18\end{array}$ & $\begin{array}{r}28 \\
183\end{array}$ & $\begin{array}{r}27 \\
143\end{array}$ & $\begin{array}{r}1 \\
28\end{array}$ & $\begin{array}{r}0 \\
12\end{array}$ & $\begin{array}{r}3 \cdot 5 \\
15 \cdot 3\end{array}$ \\
\hline $\begin{array}{l}12 \\
12\end{array}$ & $\begin{array}{r}0 \\
12\end{array}$ & $\begin{array}{r}29 \\
285\end{array}$ & $\begin{array}{r}27 \\
139\end{array}$ & $\begin{array}{r}2 \\
131\end{array}$ & $\begin{array}{r}0 \\
15\end{array}$ & $\begin{array}{r}6 \cdot 8 \\
46 \cdot 0\end{array}$ \\
\hline $\begin{array}{l}16 \\
16\end{array}$ & $\begin{array}{l}0 \\
8\end{array}$ & $\begin{array}{r}43 \\
209\end{array}$ & $\begin{array}{l}34 \\
40\end{array}$ & $\begin{array}{r}9 \\
157\end{array}$ & $\begin{array}{r}0 \\
12\end{array}$ & $\begin{array}{l}20 \cdot 9 \\
75 \cdot 1\end{array}$ \\
\hline
\end{tabular}

* Oocytes in which the stage of maturation could not be recognized by phase-contrast microscopy.

Table 3. Fusion and culture of pig oocytes in medium with cycloheximide

\begin{tabular}{|c|c|c|c|c|c|c|c|c|}
\hline \multirow[b]{2}{*}{$\begin{array}{l}\text { Type of } \\
\text { fusion }\end{array}$} & \multirow[b]{2}{*}{$\begin{array}{c}\text { Medium with } \\
\text { cycloheximide } \\
(25 \mu \mathrm{g} / \mathrm{ml})\end{array}$} & \multirow[b]{2}{*}{$\begin{array}{c}\text { Culture } \\
\text { after } \\
\text { fusion (h) }\end{array}$} & \multirow[b]{2}{*}{$\begin{array}{l}\text { No. of } \\
\text { fused } \\
\text { cells }\end{array}$} & \multicolumn{5}{|c|}{ No. of cells with: } \\
\hline & & & & $2 \mathrm{M} \mathrm{I}$ & $\mathrm{M} \mathrm{I}+\mathrm{PCC}$ & $\begin{array}{l}2 \text { clumps of } \\
\text { chromatin }\end{array}$ & $\begin{array}{l}\text { 1 clump of } \\
\text { chromatin } \\
+1 \mathrm{GV}\end{array}$ & $2 \mathrm{GVs}$ \\
\hline $\mathrm{MI}+\mathrm{GV}$ & - & 3 & 18 & & 16 & 26 & 5 & 2 \\
\hline$M I+M I$ & - & $\begin{array}{l}3 \\
3\end{array}$ & $\begin{array}{l}14 \\
24\end{array}$ & 14 & & 22 & & 2 \\
\hline
\end{tabular}

$\mathrm{GV}$, oocytes fused immediately after isolation from follicles; M I, oocytes cultured for $24 \mathrm{~h}$ before fusion; PCC, prematurely condensed chromosomes.

with cycloheximide led to GVBD in $75 \%$ of oocytes. All preincubated oocytes that did not resume meiosis in the presence of cycloheximide contained germinal vesicles at stages I or II.

The fusion of pig oocytes in metaphase I with one oocyte at the germinal vesicle stage revealed that cycloheximide did not inhibit GVBD induced by maturing ooplasm (Table 3). However, the 
behaviour of metaphase and prematurely condensed chromosomes was quite different in control experiments and in experiments with cycloheximide. After $3 \mathrm{~h}$ of culture in the control medium, the fused cells had perfect groups of metaphase I and prematurely condensed chromosomes. Induction of prematurely condensed chromosomes occurred in all fused cells. However, after $3 \mathrm{~h}$ in medium with cycloheximide, individual bivalents had a tendency to aggregate together and form one or two clumps of condensed chromatin. To confirm this effect of cycloheximide on metaphase I chromosomes, 2 oocytes in metaphase I were used and cultured with or without cycloheximide. While the metaphase I configuration in the fused cells was quite typical in the culture medium, the presence of cycloheximide induced, $3 \mathrm{~h}$ after fusion, formation of chromatin clumps as described above.

In four instances two germinal vesicles were found in giant cells. These particular cases were apparently caused by fusion of two oocytes both containing germinal vesicles instead of being at metaphase I. The probability that the oocytes chosen for fusion had remained in the germinal vesicle stage is very low, because $80-90 \%$ of them progressed after $24 \mathrm{~h}$ of culture to late diakinesis or metaphase I. However, in our experiments obviously oocytes that did not progress beyond the germinal vesicle stage were taken.

\section{Discussion}

The present results have revealed a high sensitivity of pig oocytes to cycloheximide since GVBD was prevented even at a concentration $1 \mu \mathrm{g}$ cycloheximide $/ \mathrm{ml}$. Under the same culture conditions, GVBD of mouse oocytes was insensitive to this inhibitor of protein synthesis. These experiments indicate the substantial species differences in the requirement of protein synthesis for GVBD. The results of Ekholm \& Magnusson (1979) show that this difference may be related to the time sequence of GVBD. When maturation of rat oocytes is prevented by dibutyryl cAMP and protein synthesis is blocked concomitantly, subsequent culture with puromycin alone inhibits GVBD. These results indicate the existence of short-lived proteins in fully grown rodent oocytes which are necessary for rapid GVBD (Donahue, 1968; Zeilmaker, Vermeiden, Verhame \& van Vliet, 1974). The continuous presence of puromycin leads to the depletion of these proteins which may be analogous to the tyrosine-rich short-lived proteins synthesized during the first $3 \mathrm{~h}$ of maturation in mouse oocytes (Mangia \& Canipari, 1977). The high sensitivity of pig oocytes to cycloheximide indicates that specific proteins necessary for GVBD are not present in the ooplasm of fully grown immature pig oocytes. When cycloheximide treatment was given after preincubation for 6,12 or $16 \mathrm{~h}, \mathrm{GVBD}$ was observed in 15,46 and $75 \%$ of pig oocytes, respectively, indicating that active protein synthesis in the period preceding chromatin condensation (10-14 h of culture) is necessary for the resumption of nuclear maturation. Significant changes in the pattern of protein synthesis before GVBD in pig oocytes support this conclusion (McGaughey \& Van Blerkom, 1977). Pig oocytes with more or less condensed bivalents in the nucleoplasm (GV III and GV IV) were not blocked by cycloheximide. Similarly, in progesterone-treated toad (Xenopus) oocytes, the later cycloheximide treatment is initiated, the higher the number of oocytes that undergo GVBD (Wasserman \& Masui, 1975). The resistance of toad oocytes to cycloheximide coincides with the time at which the maturation promoting activity rapidly increases. This observation indicates that only the initial phase of induction of this activity may be inhibited by cycloheximide, but further amplification of the maturation-inhibiting activity is resistant to the inhibitor. Maturation-inhibiting activity also occurs in the cytoplasm of growing pig oocytes because nuclear maturation of fully grown oocytes is blocked after homologous fusion (Fulka, Motlík, Fulka \& Crozet, 1985). This inhibiting activity can be gradually overcome by preincubation of fully grown oocytes. The length of the preincubation interval leading to the abolition of maturation-inhibiting activity well coincides with the sensitive period of pig oocytes to cycloheximide observed in the present experiments. It is possible that the oocytes preincubated for $12 \mathrm{~h}$ possessed the active molecules of maturation 
promoting factor and their further amplification cannot be prevented by cycloheximide or by the maturation inhibiting activity of growing oocytes.

In accordance with observations of toad oocytes (Wasserman \& Masui, 1975), maturation promoting activity of maturing ooplasm induced prematurely condensed chromosomes in the fused oocytes, even in the presence of cycloheximide. However, after $3 \mathrm{~h}$ in medium with cycloheximide individual bivalents had a tendency to aggregate and to form one or two clumps of condensed chromatin. We have concluded that the induction of prematurely condensed chromosomes by maturing ooplasm does not require protein synthesis, but that continuous protein synthesis is necessary to maintain metaphase I and prematurely condensed chromosomes in a typical configuration. In contrast, Clarke \& Masui $(1983,1985)$ treated mouse oocytes with puromycin and observed formation of the first polar body and transformation of chromosomes to interphase nuclei. The opposite behaviour of chromosomes in our experiments with pig oocytes might have been caused by a qualitative difference in proteins synthesized at the time of inhibitor application.

\section{References}

Clarke, H.J. \& Masui, Y. (1983) The induction of reversible and irreversible chromosome decondensation by protein synthesis inhibition during meiotic maturation of mouse oocytes. Devl Biol. 97, 291-301.

Clarke, H.J. \& Masui, Y. (1985) Inhibition of dibutyryl cyclic AMP of the transition to metaphase of mouse oocyte nuclei and its reversal by cell fusion to metaphase oocytes. Devl Biol. 108, 32-37.

Donahue, R.P. (1968) Maturation of the mouse oocyte in vitro. I. Sequence and timing of nuclear progression. J. exp. Zool. 169, 237-250.

Ekholm, C. \& Magnusson, C. (1979) Rat oocyte maturation: effects of protein synthesis inhibitors. Biol. Reprod. 21, 1287-1293.

Fulka, J., Jr, Motlík, J., Fulka, J. \& Crozet, N. (1985) Inhibition of nuclear maturation in fully grown porcine and mouse oocytes after their fusion with growing porcine oocytes. J. exp. Zool. 235, 255-259.

Mangia, F. \& Canipari, R. (1977) Biochemistry of growth and maturation in mammalian oocytes. In Development in Mammals, Vol. 2, pp. 1-29. Ed. M. H. Johnson. North Holland Publishing Company, Amsterdam.

McGaughey, R.W. \& Van Blerkom, J. (1977) Patterns of polypeptide synthesis of porcine oocytes during maturation in vitro. Devl Biol. 56, 241-254.

Motlik, J. \& Fulka, J. (1976) Breakdown of the germinal vesicle in pig oocytes in vivo and in vitro. $J$. exp. Zool. 198, 155-162.
Osborn, J.C. \& Moor, R.M. (1983) Time-dependent effects of $\alpha$-amanitin on nuclear maturation and protein synthesis in mammalian oocytes. J. Embryol. exp. Morph. 73, 317-338.

Schultz, R.M. \& Wassarman, P.M. (1977) Biochemical studies of mammalian oogenesis: protein synthesis during oocyte growth and meiotic maturation in the mouse. J. Cell Sci. 24, 167-194.

Van Blerkom, J. \& McGaughey, R.W. (1978) Molecular differentiation of the rabbit ovum. 1. During oocyte maturation in vivo and in vitro. Devl Biol. 63, $139-150$.

Warnes, G.M., Moor, R.M. \& Johnson, M.H. (1977) Changes in protein synthesis during maturation of sheep oocytes in vivo and in vitro. J. Reprod. Fert. 49, $331-335$.

Wasserman, W.J. \& Masui, Y. (1975) Effects of cycloheximide on a cytoplasmic factor initiating meiotic maturation in Xenopus oocytes. Expl Cell Res. 91, 381-388.

Zeilmaker, G.H., Vermeiden, J.P.W., Verhame, C.M.P.M. \& van Vliet, A.C.W. (1974) Observations on rat and mouse maturation in vivo and in vitro: morphology and physiology. Eur. J. Obstet. Gynec. Reprod. Biol. 4, 15-24.

Received 3 October 1985 